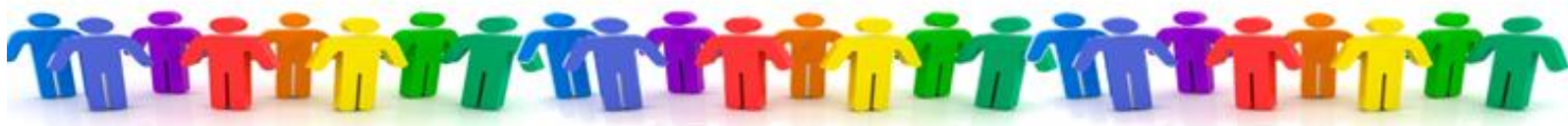

\section{Social Class Differences in Social Integration at University: Implications for Academic Outcomes and Mental Health}

\author{
Mark Rubin, Olivia Evans, \& Romany McGuffog \\ The University of Newcastle, Australia
}

Citation: Rubin, M., Evans, O., \& McGuffog, R. (2019). Social class differences in social integration at university: Implications for academic outcomes and mental health. In J. Jetten, \& K. Peters (Eds.), The social psychology of inequality (pp. 87-102). Springer. https://doi.org/10.1007/978-3-030-28856-3_6

\begin{abstract}
University represents a pathway to upward social mobility for many working-class people. However, this distinctly middle-class environment also provides a number of unique social psychological challenges for working-class students. Working-class university students are often in the minority group at university, they are often the first in their families to attend university, and they often feel out of place at university. They also lack the time and money required to engage with other students on campus. Consequently, they are less likely to be as integrated into social life at university as their middle-class peers. In this chapter, we consider the potential implications of this lack of social integration for working-class students' academic outcomes and mental health. In particular, we review recent research that shows that working-class students' lack of integration at university is associated with poorer academic outcomes and poorer mental health. We conclude with a discussion of potential interventions to increase working-class students' social integration at university.
\end{abstract}

Keywords: academic performance; low SES students; mental health; social class; social integration; university students; working-class students

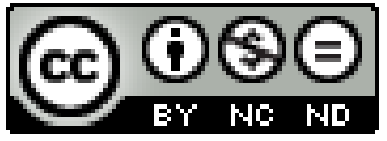

Copyright (C) The Authors. OPEN ACCESS: This material is published under the terms of the Creative Commons Attribution-NonCommercial-NoDerivatives 4.0 International licence (CC BY-NC-ND 4.0; https://creativecommons.org/licenses/bync-nd/4.0/). This licence permits you to copy and redistribute this material in any medium or format for noncommerical purposes without remixing, transforming, or building on the material provided that proper attribution to the authors is given.

This self-archived article is provided for non-commercial and scholarly purposes only.

Correspondence concerning this article should be addressed to Mark Rubin at the School of Psychology, Behavioural Sciences Building, The University of Newcastle, Callaghan, NSW 2308, Australia. Tel: +61 (0)2 4921 6706. Fax: +61 (0)2 4921 6980. E-mail: Mark.Rubin@newcastle.edu.au Web: http://bit.ly/QgpV4O Twitter: @RubinPsyc 
Many of society's inequalities are manifest in, and propagated by, the education that we receive. Higher education in particular represents a key gateway for social mobility. Without a higher education, people are likely to work in lower-status and poorer-paying jobs (Day \& Newburger, 2002; Pascarella \& Terenzini, 1991, 2005; Perna, 2005). With the goal of equality and equal opportunity in mind, there has been a widening of participation by minority groups in higher education over the last few decades (e.g., Shah, Bennett, \& Southgate, 2016; Yu \& Delaney, 2016). In particular, in the UK, USA, and Australia, as well as many other countries, there has been a push to increase the proportion of working-class ${ }^{1}$ students in higher education.

However, this expansion of higher education is happening at a relatively slow rate, with all countries' higher education systems failing to reflect the diversity of their general populations despite years of equal opportunity policies. For example, in Australia, 25\% of the general population are classified as having a low socio-economic status (SES; Department of Education, Employment and Workplace Relations, 2009). However, the percentage of commencing low SES university students was $16.08 \%$ in 2015 and has only increased by 5\% over the past 5 years (Parker, 2016). Consequently, as it currently stands, higher education serves to reinforce social inequality, because working-class people are not adequately represented in higher education and are thus not reaping the social and economic benefits at the same rate as middle- and upper-class people.

This lack of adequate representation is especially problematic because working-class people have a lot to gain from higher education. In particular, a university education is an important means of achieving upward social mobility. Indeed, higher education may be more beneficial for working-class people than for middle-class people in terms of subsequent economic earnings (Brand \& Xie, 2010).

Furthermore, what increase in the proportion of working-class students there has been in higher education has not proven to be a panacea to social inequality. Indeed, it might be argued that as working-class participation has increased, so too has social inequality (Kromydas, 2017). This is because the demographics, culture, and family experiences of middle- and upper-class students provide them with certain advantages over working-class students during their time at university (Parker, 2016).

In particular, working-class students' minority group status is more salient at university than in primary and secondary education settings. This is because primary and secondary schools draw from local populations that reflect students' own SES background, whereas universities draw from a more distinctly middle-class population. Consequently, working-class students' minority group status is more evident at university than in their prior educational settings, and this may lead them to feel out of place at university (Croizet, Austin, Goudeau, Marot, \& Millet, 2019; Easterbrook, Hadden \& Nieuwenhuis, 2019).

Additionally, universities are distinctly middle-class environments that include their own norms and cultural values that can clash with working class values (Rubin, Denson, Kilpatrick, Matthews, Stehlik, \& Zyngier, 2014; see also Batruch, Autin \& Batura, 2019). More specifically, universities embody a middle-class independent approach to learning and achievement, which is discordant with interdependent working-class values, making university more alien and difficult for working-class students (Stephens, Fryberg, Markus, Johnson, \& Covarrubias, 2012).

Finally, working-class students are often the first in their families to attend university. Consequently, working-class families have less experience with universities and are often unable to provide the same level of financial, informational, mentoring, and/or identity support as middleclass families do to their sons and daughters (Rubin, 2012b). 
In summary, compared to middle-class university students, working-class students tend to be disadvantaged numerically, culturally, and in terms of their family support. These differences may help to explain a number of social class inequalities in higher education. Compared to middleclass students, working-class students are often less prepared for higher education (e.g., Bui, 2002; Reid \& Moore III, 2008; Shields, 2002), less likely to be academically engaged after enrolment (e.g., Martinez, Sher, Krull, \& Wood, 2009; Pike \& Kuh, 2005), less likely to obtain good grades and develop intellectually (for a meta-analysis, see Robbins, Le, Davis, Lauver, Langley, \& Carlstrom, 2004), less likely to stay enrolled in their courses (e.g., Inman \& Mayes, 1999), less likely to complete their degrees (for a meta-analysis, see Robbins et al., 2004), and less likely to be satisfied with their university experience (Martin, 2012). They are also more likely to suffer from poorer mental health at university (Evans, 2019; Rubin, Evans, \& Wilkinson, 2016; Rubin \& Kelly, 2015).

In this chapter, we focus on two of these social class differences at university: academic outcomes and mental health. We consider the extent to which social class differences on each of these variables may be related to social class differences in social integration at university. In particular, we consider recent research that shows that working-class students' relatively low degree of social integration at university is associated with their poorer academic outcomes and their poorer mental health. However, before proceeding, it is necessary to take a step back and clarify what we mean by social class and social integration.

\section{What is Social Class?}

We conceptualize social class as a multidimensional latent construct that is based on an interaction between people's social, cultural, and economic background and status (Rubin, et al., 2014). Social class can be distinguished from SES in terms of its stability. Because it has a cultural basis, social class is a relatively stable variable that is likely to change slowly and slightly over several years. In contrast, because it has an economic basis, an individual's SES is a more mutable variable that has the potential to change more quickly depending on the individual's current income and assets. Hence, an individual may have a relatively high SES and yet continue to identify as a working-class person (Rubin et al., 2014).

Our definition of social class has three implications for measurement. First, consistent with our view that social class is a multidimensional variable, we use several different measures of social class in our research surveys. For example, we include measures of parental education, parent occupation, family income, self-identified social class, and subjective social status.

Second, consistent with our view that social class is a latent variable, we aggregate across different measures of social class in order to form a global index of social class. In most cases, this approach is supported by the results of exploratory factor analyses, which show that our measures of social class load on a single factor.

Third, we avoid a categorical approach in which participants are allocated to discrete categories such as "working class" or "middle class." This decision is based on theoretical, pragmatic, and statistical reasons. Theoretically, we are primarily concerned with general associations between social class and other variables rather than with specific categories of social class. Pragmatically, decisions about the cut-points for such categories are arbitrary, contextspecific, and often difficult to justify (Rubin et al., 2014). Finally, from a statistical perceptive, the categorical approach ignores potentially important intracategory differences in social class. Hence, it may involve grouping people together as "working-class" when, in fact, there is a substantial degree of variability in social class within this category. 
To be clear, we use the terms "working-class students" and "middle-class students" when reporting our research results because this conventional terminology aids in the communication of the work. For a similar reason, our measures ask participants to indicate whether they and their parents are "working-class," "lower middle-class," "middle-class," "upper middle-class," or "upper class." However, our index of social class is one that aggregates across several different measures of social class to create a continuous measure. Hence, while we refer to "working class" or "lower class" individuals in this chapter, these terms refer generally to people at the lower end of the social class spectrum rather than to people who are specifically categorized as being "working class." Similarly, "middle class" and "upper class" refer generally to those toward the middle or top of the social class spectrum.

\section{What is Social Integration?}

Like social class, social integration has many different definitions and operationalizations (e.g., Gellin, 2003, p. 748; Wolf-Wendel, Ward, \& Kinzie, 2009). Again, we define social integration as a multidimensional latent construct. Specifically, in a university setting, social integration refers to the quantity and quality of social interactions with staff and students, the sense of connection with these people, and a sense of belonging to the university as a whole. Hence, our measures of social integration refer to the number of university friends that students have, time spent socializing in face-to-face meetings and in online environments (e.g., Facebook), the extent of participation in the university context, the perceived quality of university friendships, and sense of belonging and loneliness.

Again, exploratory factor analyses tend to show that these various aspects of social integration load on a single factor. Consequently, like social class, we analyse social integration as a single continuous index.

\section{Social Class and Social Integration at University}

As we have established, disparities in higher education are a contributing factor to social inequality. In particular, working-class students face disadvantages at university with regards to their academic outcomes and mental health. In this chapter, we propose that a lack of social integration at university may help to explain working-class students' poorer academic and mental health outcomes. Consistent with this proposal, a substantial body of research shows that workingclass students are less socially integrated at university compared with middle-class students (for recent evidence, see Langhout, Drake, \& Rosselli, 2009; Martin, 2012; Ostrove \& Long, 2007; Stuber, 2009; for meta-analyses, see Robbins et al., 2004; Rubin, 2012a). Rubin's (2012a) metaanalysis of 35 (mainly USA) studies showed that, compared with middle-class students, workingclass students feel less of a sense of belonging to their universities and participate in fewer formal social activities (e.g., campus clubs and organizations) and fewer informal social activities (e.g., drinks, dates, \& conversations). This social exclusion effect generalizes across men and women as well as people of different ethnicities. The effect also holds across years of study, indicating that time spent at university does not eradicate these differences. Hence, the positive relation between social class and social integration is a relatively widespread and pervasive association in university student populations.

Why do working-class students integrate less at university? Answers to this question seem to fall into two main categories that relate to the personal context of working-class students and the institutional context of universities. With regards to personal context, working-class students tend to have different life circumstances to middle-class students. In particular, working-class 
students come to university at different times in their lives and have different, often more restrictive commitments. Consistent with this view, Rubin and Wright $(2015,2017)$ found that (a) workingclass students tended to be older than higher-class students, (b) older students tended to have more paid work and childcare commitments than younger students, (c) students with more of these commitments tended to spend less time on their university campus, and (d) students who spent less time on campus tended to be less socially integrated at university. Rubin and Wright also found that working-class students tended to be less satisfied with their finances, and that this social class difference in financial satisfaction helped to explain their lack of social integration.

Working-class students' lack of time and money seems to be particularly obstructive to their social experience at university. Working-class students are more likely to work to support themselves through university, and this paid work can result in less time for them to socialise with other students. Working-class students also have less money to purchase items associated with social experiences (e.g., tickets, entrance fees, food, drinks, etc.). Both of these issues were raised in Lehmann's (2009) interviews with working-class students. When discussing the impact of working while going to university, one student lamented, "it's going to cut into my social time" (p. 637). When discussing the disconnection with university friends, another student confided, "it is really difficult for me to have to go to work and to always be strapped" (p. 637). Thus, a clear reason that explains why working-class students are less integrated is that they have less time and money to participate in social activities at universities.

Turning to institutional context, research suggests that working-class students do not feel comfortable at university because it is a middle-class sociocultural environment. Indeed, several qualitative studies include reports from working-class students that describe their discomfort with the university culture, campus, student identity, and other students (e.g., Bergerson, 2007; Karimshah, Wyder, Henman, Tay, Capelin, \& Short, 2013; Lehmann, 2007). Research on the cultural mismatch between working-class culture and university culture is also consistent with the institutional context viewpoint. As a bastion of middle-class culture, universities tend to promote the middle-class cultural value of independence, rather than the working-class value of interdependence (Manstead, 2018; Stephens, Townsend, Markus \& Phillips, 2012). This cultural mismatch between working-class values and university values has a detrimental effect on workingclass students' motivations (Stephens, Fryberg, et al., 2012), networking behaviour (Soria \& Stebleton, 2013), and expectations about university (Stephens, Hamedani, \& Destin, 2014).

In summary, a number of factors contribute to social class differences in social integration, including factors that relate to both the circumstances of the student and the university context. It is important to take these factors into consideration because, by not being fully socially integrated at university, working-class students are missing out on a crucial aspect of the university experience that has numerous flow on effects. Below, we discuss the effects on academic outcome and mental health.

\section{Social Class, Social Integration, and Academic Outcomes}

Several studies have shown that social class is positively related to academic performance. For example, Robbins et al.'s (2004) meta-analysis of 109 (all USA) studies found that higher SES predicts higher grade point average. Similar results have been found by Robbins, Allen, Casillas, Peterson and Le (2006) and Pittman and Richmond (2007). In Australia, Southgate, Douglas, Scevak, MacQueen, Rubin, and Lindell (2014) found that first-generation university students had similar academic results to other students in first year. However, the social class academic performance gap opened up in subsequent years. Southgate et al. suggested that this change may 
be because the university used in their study provided numerous resources to help first-generation students in their first year of study, but this assistance was not as prominent in subsequent years.

There is also a wealth of research which shows that social class is related to other academic outcomes. For example, working-class and first-generation students are less likely than middleclass and continuing-generation students to be academically engaged (e.g., Martinez et al., 2009; Pike \& Kuh, 2005; Soria \& Stebleton, 2013), less likely to develop intellectually (for a metaanalysis, see Robbins et al., 2004), less likely to cope with the academic workload and complexity of the course material (Scevak, Southgate, Rubin, Macqueen, Douglas, \& Williams, 2015), and more likely to withdraw from their courses (Inman \& Hayes, 1999; Riehl, 1994; Scevak et al., 2015) and their degrees (Martin, Maclachlan \& Karmel, 2001; Vickers, Lamb \& Hinkley, 2003; for a meta-analysis of six tests, see Robbins et al., 2004).

Social integration at university may play a key role in explaining these social class differences in academic outcomes. Social integration is related to students' academic development, outcomes, and retention (for reviews, see Pascarella \& Terenzini, 1991, 2005). In particular, social integration is related to better learning, cognitive growth, critical thinking, and personal and moral development (for reviews, see Gellin, 2003; Hernandez, Hogan, Hathaway, \& Lovell, 1999; McConnell, 2000). Social integration is also related to better academic performance (for a metaanalysis of 33 tests, see Robbins et al., 2004) and greater persistence and retention (for a metaanalysis of 36 tests, see Robbins et al., 2004; for narrative reviews, see McConnell, 2000). Additionally, experimental and longitudinal evidence suggests that greater social integration causes better academic outcomes (Walton \& Cohen, 2007) and persistence (Berger \& Milem, 1999; Cabrera, Castañeda, Nora, \& Hengstler, 1992).

There are a number of reasons why social integration may help to explain the association between social class and academic outcomes (Rubin, 2012b). Social integration can provide students with informational support (e.g., Collier \& Morgan, 2008, p. 436-437; Gallagher \& Gilmore, 2013), emotional support (e.g., Wilcox, Winn, \& Fyvie-Gauld, 2005; Zorn \& Gregory, 2005), motivational support (e.g., Harackiewicz, Barron, \& Elliot, 1998), mentoring (e.g., Tremblay \& Rodger, 2003), and identity support (e.g., Braxton et al., 1997, p. 123; Robbins et al., 2006, p. 604). In theory, each of these different kinds of support may be especially beneficial for working-class students' academic performance precisely because working-class students lack these forms of support. For example, working-class students tend to lack information and social support for their university studies from their family and hometown friends (e.g., Bryan \& Simmons, 2009, p. 398; Elkins, Braxton, \& James, 2000; Lehmann, 2009, p. 638), and social integration provides access to these types of support from other students at university (Wilcox et al., 2005; Zorn \& Gregory, 2005). Consistent with this deficit perspective, there is some evidence that participation in social activities has a significantly stronger positive effect on academic-related variables for working-class students than it does for middle-class students, both at school and at university (e.g., Blomfield \& Barber, 2011; Malecki \& Demaray, 2006; Pascarella, Pierson, Wolniak, \& Terenzini, 2004). Hence, improving the social integration of working-class university students represents a potential method of closing the social class gap in academic outcomes.

In summary, (a) social class is related to academic outcomes, (b) social class is related to social integration at university, and (c) social integration at university is related to academic outcomes. Consequently, working-class students' deficit in academic outcomes may be mediated by their deficit in social integration into university life. A study by Yazedjian, Toews, and Navarro (2009) aimed to investigate this mediation model. Yazedjian et al.'s study consisted of 883 participants from a Texas university. The researchers found that social class differences (as 
measured by parental education level) in adjustment to university accounted for social class differences in grade point average among white students but not Hispanic students. Further research in other university student populations is needed to investigate the mediating effect of social integration in the association between social class and academic performance.

Importantly, working class students' lack of social integration at university has a broader impact beyond that of their academic performance. It also has a negative impact on their health and well-being. Below, we discuss research on the relationship between social class, social integration, and university students' mental health.

\section{Social Class, Social Integration, and Mental Health}

Social class is positively related to mental health in the general population (for a review, see Lund et al., 2010). For example, a meta-analysis of 51 studies found that working-class people are more likely to be depressed than middle-class people (Lorant, Deliège, Eaton, Robert, Philippot \& Ansseau, 2003). Hence, it is not surprising that social class also positively predicts mental health in university populations (e.g., King, Garrett, Wrench \& Lewis, 2011; Said, Kypri, \& Bowman, 2013; Rubin \& Kelly, 2015; Rubin \& Stuart, 2018). However, this association between social class and mental health is particularly concerning among university students because, independent of their social class, university students already represent a high-risk group for mental health problems. For example, in the USA, the 2015 National College Health Assessment II found that $18.6 \%$ of students reported having been diagnosed with depression (American College Health Association, 2015) as opposed to only $6.7 \%$ in the U.S. general population (National Institute of Medical Health, 2015). Similarly, in Australia, 19.2\% of students at two large universities had "very high" levels of mental distress compared to only $3 \%$ in the general population (Stallman, 2010). Hence, when it comes to mental health, working-class university students face a doublejeopardy of being both (a) working-class and (b) university students.

Again, social integration may help to explain social class differences in mental health at university. Consistent with this possibility, social integration has beneficial effects on mental health (for a review, see Hefner \& Eisenberg, 2009), including at university (McIntyre, Worsley, Corcoran, Harrison Woods, \& Bentall, 2018), most likely because it facilitates self-esteem, a sense of belonging, self-disclosure, and perceived social support (Rubin \& Kelly, 2015; Thoits, 2011).

Direct evidence that social integration mediates the association between social class and mental health comes from Rubin and Kelly (2015) and Rubin et al. (2016). Rubin and Kelly surveyed a sample of 397 psychology undergraduate students at an Australian university. They found that, compared to middle-class students, working-class students experienced (a) worse social integration at university and (b) worse mental health (measured using the Depression, Anxiety, and Stress Scale [DASS]; Lovibond \& Lovibond, 2004). In addition, social class differences in social integration mediated the relation between social class and mental health. In other words, working-class students' poorer social integration helped to explain their poorer mental health.

Rubin and Kelly's (2015) cross-sectional study did not provide causal evidence of these relationships. To address this issue, Rubin et al. (2016) conducted a longitudinal study with 314 first-year undergraduate students at an Australian university. Students' social class, social integration (the number of friends made at university and the amount of contact with these friends), and mental health (DASS) were assessed over two consecutive semesters. Consistent with previous research, the results indicated that social class during Semester 1 positively predicted social integration and negatively predicted depression during Semester 2. In addition, Semester 1 social integration negatively predicted Semester 2 depression. Finally, controlling for Semester 1 social 
integration with university friends led to a significant reduction in the size of the relation between Semester 1 social class and Semester 2 depression. These results are consistent with the view that lower social status causes less social integration with university friends, which causes more depressive symptoms, and that lack of social integration explains the relation between social status and depressive symptoms.

Notably, social integration may also have a protective role against mental illness (Almedom, 2005; Rubin, 2012b; Rubin \& Kelly, 2015). Rubin and Stuart (2018) considered this issue from the perspective of social class identification. They found that when university students' social class identification was assessed in terms of perceived similarity with other members of one's social class, it moderated the association between social class and depressive symptoms. In particular, social identification buffered (reduced) the effects of social class on depressive symptoms. Critically, however, subsequent attempts to replicate this effect have not been successful, possibly due to measurement issues (Evans, 2019; McGuffog, 2018; Rubin, Paolini, Subašić, \& Giacomini, 2019). Additionally, Iyer, Jetten, Tsivrikos, Postmes, and Haslam (2009) found that identifying as a student predicted students' greater wellbeing, but that working-class students were less likely to identify as a student or to see the student identity as being compatible with their social class identity. Hence, further research is required before it can be concluded that working-class students may reap the potentially protective benefits of social class identification or student identification.

\section{Conclusions}

In summary, prior research has found social class differences in university students' academic outcomes and mental health, and recent research has identified social integration at university as a key mediator of these differences: Working-class university students appear to suffer from poorer academic outcomes and mental health in part because of their poorer integration into the social life of their universities. Figure 1 shows the variables that we believe may be involved in these relations.

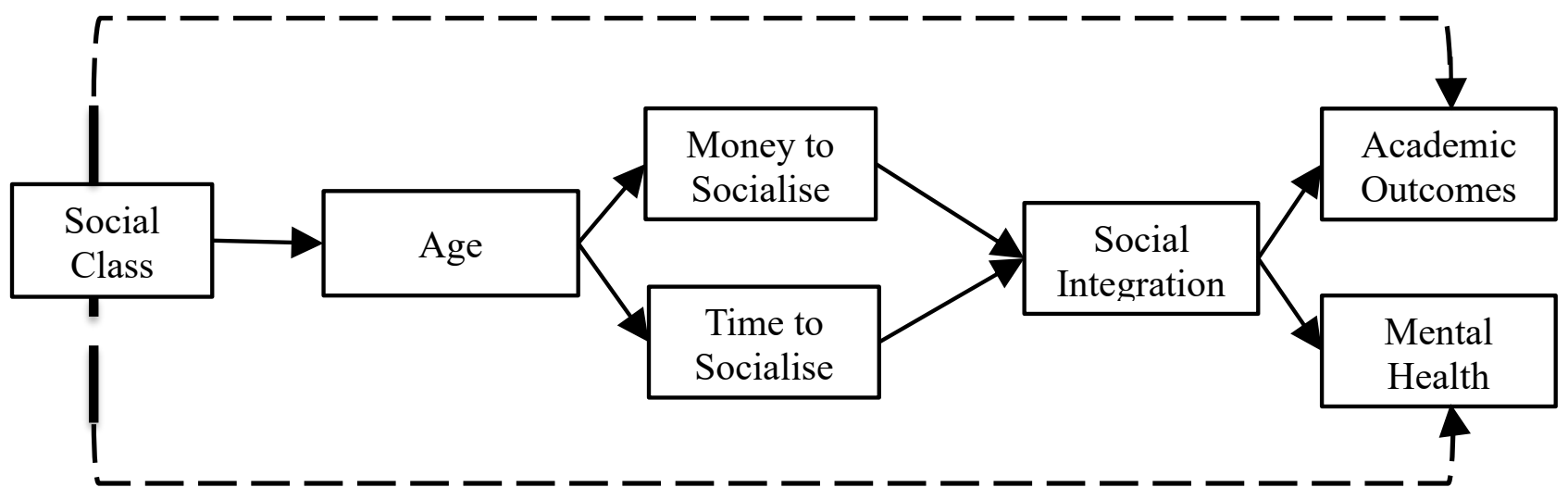

Figure 1.

Model showing how social class is associated with academic outcomes and mental health.

The model suggests that working-class university students are older than middle-class students, and that this age difference predicts a lack of time and money to socialize, resulting in 
less social integration. In turn, this lack of social integration is associated with poorer academic outcomes and mental health.

Devlin (2013) suggested that social class inequalities in higher education are caused by an interaction between student and university factors. Our own research supports this view. Workingclass students enter university with a particular set of life circumstances, including limited time and money to engage in social activities. However, these life circumstances only become problematic within the particular majority middle-class institutional context of university. It is important to appreciate, however, that from an interventionist perspective, it may be more difficult to change the life circumstances of working-class students than to change the institutional context of universities. For this reason, we believe that the onus is on universities to adapt to workingclass students rather than vice versa. Indeed, to be successful, the widening participation agenda must entail an active participation on the part of universities as well as students. As Enstrom and Tinto (2008) put it so succinctly, "access without support is not opportunity" (p. 50), and governments and universities have a responsibility to provide support as well as access. Critically, to be successful, this support needs to be operationalized at social and cultural levels and not only at the academic level.

Socially, universities need to consider ways of facilitating working-class students' social integration. Rubin and Wright $(2015,2017)$ suggested that this facilitative approach needs to be carefully thought through and adjusted to the particular needs and life circumstances of workingclass students. For example, on campus accommodation needs to be subsidized and to take into consideration the fact that many working-class students are also mature-aged students with family commitments. Similarly, social activities need to be subsidized, pitched at the right age group, and held at times and places that are convenient for working-class students. Finally, on-campus employment and childcare should adopt an affirmative action approach towards working-class students.

It is also worth thinking outside of the box when it comes to working-class students' social integration. In this vein, Rubin and Wright $(2015,2017)$ suggested that universities should develop online forms of social integration that do not require campus attendance. Online social networking sites such as Facebook represent one such approach. There is already substantial international evidence that frequency and intensity of Facebook use are associated with greater social integration at university (e.g., Komarenko, 2016; Morioka, Ellison, \& Brown, 2016; for a review, see Ternes, 2013). There is also recent evidence that certain types of Facebook use improve mental well-being among university students (e.g., Hu, Kim, Siwek, \& Wilder, 2017; Zhang, 2017; for reviews, see Frost \& Rickwood, 2017; Verduyn, Ybarra, Résibois, Jonides, \& Kross, 2017). Importantly, many online social networking platforms are free, and they allow users to access important social networks without needing to attend social events in person. These characteristics make online social networking sites attractive to working-class students, who often have less time and money to engage in traditional face-to-face social activities (Rubin \& Wright, 2017). Perhaps for these reasons, there is some evidence that low SES students use Facebook more than high SES students (Strayhorn, 2012).

Importantly, working-class students also need to be motivated to take advantage of the opportunities for integration that universities provide, and this may be the most difficult problem to address. Rubin and Wright (2015) found that working-class students had less desire and concern about making new friends than middle-class students. Additionally, as discussed previously, working class students are also less likely to adopt a student identity and are less likely to view a student identity as being compatible with their existing identities (Iyer et al., 2009). Each of these 
phenomena could be due to the university environment generally being thought of as a middleclass environment propagating middle-class values. Universities are stereotypically traditional institutions that are quite resistant to cultural change. However, in order to survive in an era of widening participation, universities need to learn and adopt the values of their students as much as students need to learn and adopt the values of universities.

Finally, in a broader context, the current widening of participation in universities seems to be partly reinforcing inequality. As we noted at the beginning of this chapter, the number of working class students has been increasing, albeit slowly, over the last few decades. However, when taking a closer look at where these changes are coming from, it is the rural and outer-urban universities in Australia, or the community colleges in America, that are expanding most rapidly in terms of working-class students (Chesters, 2015; Gurney-Read, 2015; Jaschik, 2012; Parker, 2016). Comparatively, the more prestigious universities in capital cities have had relatively little change in the proportion of working-class students. With the massification and diversification of higher education, university prestige is fast becoming a key factor in distinguishing between graduates and determining the benefits that graduates can obtain from their degrees (Chesters, 2015). Thus, although there may be a more equal opportunity of access to higher education, not all higher education opportunities are equal. This current trend, in which middle- and upper-class students are more likely to attend universities with the most social and economic capital, appears to preserve rather than improve social inequalities. On a global level, the higher education sector should take a more egalitarian approach to enrolments in which elite institutions take their fair share of economically disadvantaged students. Alternatively, the system needs to change such that the capacity for institutions to create value for their students is more broadly and evenly distributed across the sector.

\section{References}

Almedom, A. M. (2005). Social capital and mental health: An interdisciplinary review of primary evidence. Social Science \& Medicine, 61, 943-964. doi: 10.1016/j.socscimed.2004.12.025

American College Health Association. (2015). American college health association-national college health assessment II: Undergraduate students reference group data report Spring 2015. Hanover, MD: American College Health Association.

Batruch, A., Autin, F., \& Butera, F. (2019). The paradoxical role of meritocratic selection in the perpetuation of social inequalities at school. In J. Jetten, \& K. Peters (Eds.), The social psychology of inequality (pp. 123-138). Springer. doi: 10.1007/978-3-030-28856-3_8

Berger, J. B., \& Milem, J. F. (1999). The role of student involvement and perceptions of integration in a causal model of student persistence. Research in Higher Education, 40, 641-664. doi: 10.1023/A:1018708813711

Bergerson, A. A. (2007). Exploring the impact of social class on adjustment to college: Anna's story. International Journal of Qualitative Studies in Education, 20, 99-119. doi: $\underline{10.1080 / 09518390600923610}$

Blomfield, C. J., \& Barber, B. L. (2011). Developmental experiences during extracurricular activities and Australian adolescents' self-concept: Particularly important for youth from disadvantaged schools. Journal of Youth and Adolescence, 40, 582-594. doi: 10.1007/s10964-010-9563-0

Brand, J. E., \& Xie, Y. (2010). Who benefits most from college? Evidence for negative selection in heterogeneous economic returns to higher education. American Sociological Review, 75, 273-302. doi: $10.1177 / 0003122410363567$ 
Bryan, E., \& Simmons, L. A. (2009). Family involvement: Impacts on post-secondary educational success for first-generation Appalachian college students. Journal of College Student Development, 50, 391-406. doi: 10.1353/csd.0.0081

Bui, K. T. (2002). First-generation college students at a four-year university: Background characteristics, reasons for pursuing higher education, and first-year experiences. College Student Journal, 36, 3-11.

Cabrera, A. F., Castaneda, M. B., Nora, A., \& Hengstler, D. (1992). The convergence between two theories of college persistence. The Journal of Higher Education, 63, 143-164. doi: $10.2307 / 1982157$

Chesters, J. (2015). Maintaining inequality despite expansion: Evidence of the link between parents' education and qualitative differences in educational attainment. Higher Education Quarterly, 69(2), 138-157. doi: 10.1111/hequ.12060

Collier, P. J., \& Morgan, D. L. (2008). "Is that paper really due today?": Differences in firstgeneration and traditional college students' understandings of faculty expectations. Higher Education, 55, 425-446. doi: 10.1007/s10734-007-9065-5

Croizet, J. -C., Autin, F., Goudeau, S., Marot, M., \& Millet, M. (2019). Education and social class: Highlighting how the educational system perpetuates social inequality. In J. Jetten, \& K. Peters (Eds.), The social psychology of inequality (pp. 139-154). Springer. doi: 10.1007/978-3-030-28856-3_9

Day, J. C., \& Newburger, E. C. (2002). The big payoff: Educational attainment and synthetic estimates of work-life earnings. Special studies. Current Population Reports. Retrieved from https://files.eric.ed.gov/fulltext/ED467533.pdf

Department of Education, Employment and Workplace Relations. (2009). Measuring the socioeconomic status of higher education students: Discussion paper. DEEWR, Canberra, Australia. Retrieved from http://hdl.voced.edu.au/10707/63937

Devlin, M. (2013). Bridging socio-cultural incongruity: Conceptualising the success of students from low socio-economic backgrounds in Australian higher education. Studies in Higher Education, 38, 939-949. doi: 10.1080/03075079.2011.613991

Elkins, S. A., Braxton, J. M., \& James, G. W. (2000). Tinto's separation stage and its influence on first-semester college student persistence. Research in Higher Education, 41, 251-268. doi: 10.1023/A:1007099306216

Easterbrook, M. J., Hadden, I. R., \& Nieuwenhuis, M. (2019). Identities in context: How social class shapes inequalities in education. In J. Jetten, \& K. Peters (Eds.), The social psychology of inequality (pp. 103-122). Springer. doi: 10.1007/978-3-030-28856-3 7

Enstrom, C., \& Tinto, V. (2008). Access without support is not opportunity. Change: The Magazine of Higher Learning, 40, 46-50. doi: 10.3200/CHNG.40.1.46-50

Evans, O. (2019). It's lonely at the bottom: Investigating the role of social integration in the association between social class and mental health. Unpublished manuscript, The University of Newcastle, Australia.

Frost, R. L., \& Rickwood, D. J. (2017). A systematic review of the mental health outcomes associated with Facebook use. Computers in Human Behavior, 76, 576-600. doi: 10.1016/j.chb.2017.08.001

Gallagher, D., \& Gilmore, A. (2013). Social integration and the role of student societies in higher education: An exploratory study in the UK. International Journal of Nonprofit and Voluntary Sector Marketing, 18, 275-286. doi: 10.1002/nvsm.1472 
Gellin, A. (2003). The effect of undergraduate student involvement on critical thinking: A metaanalysis of the literature 1991-2000. Journal of College Student Development, 44, 746-762. doi: $10.1353 / \mathrm{csd} .2003 .0066$

Gurney-Read, J. (2015, January 27). Independent school pupils 'twice as likely to attend elite universities'. The Telegraph, Retrieved from http://www.telegraph.co.uk

Harackiewicz, J. M., Barron, K. E., \& Elliot, A. J. (1998). Rethinking achievement goals: When are they adaptive for college students and why? Educational Psychologist, 33, 1-21. doi: $10.1207 / \mathrm{s} 15326985 \mathrm{ep} 3301 \_1$

Hefner, J., \& Eisenberg, D. (2009). Social support and mental health among college students. American Journal of Orthopsychiatry, 79, 491-499. doi: 10.1037/a0016918

Hernandez, K., Hogan, S., Hathaway, C., \& Lovell, C. D. (1999). Analysis of the literature on the impact of student involvement on student development and learning: More questions than answers? NASPA Journal, 36, 184-197. doi: 10.2202/1949-6605.1082

Hu, X., Kim, A., Siwek, N., \& Wilder, D. (2017). The Facebook paradox: Effects of Facebooking on individuals' social relationships and psychological well-being. Frontiers in Psychology, 8, 87. doi: $10.3389 /$ fpsyg.2017.00087

Inman, W. E., \& Mayes, L. D. (1999). The importance of being first: Unique characteristics of first-generation community college students. Community College Review, 26, 3-22. doi: 10.1177/009155219902600402

Iyer, A., Jetten, J., Tsivrikos, D., Postmes, T., \& Haslam, S. A. (2009). The more (and the more compatible) the merrier: Multiple group memberships and identity compatibility as predictors of adjustment after life transitions. British Journal of Social Psychology, 48, 707-733. doi: 10.1348/014466608X397628

Karimshah, A., Wyder, M., Henman, P., Tay, D., Capelin, E., \& Short, P. (2013). Overcoming adversity among low SES students: A study of strategies for retention. The Australian Universities' Review, 55, 5-14.

Jaschik, S. (2012, December 11). The missing student. Inside Higher Education, Retrieved from http://www.insidehighered.com

King, S., Garrett, R., Wrench, A., \& Lewis, N. (2011). The loneliness of relocating: Does the transition to university pose a significant health risk for rural and isolated students. Paper presented at the First Year in Higher Education Conference, Brisbane, Australia. Retrieved from http://fyhe.com.au/past_papers/papers11/FYHE-2011/content/pdf/16B.pdf

Komarenko, O. (2016). The relationship between college students' use of Facebook and their feelings of alienation from their institution (Doctoral dissertation). Available from ProQuest Dissertations and Theses database. (ProQuest No. 10246822)

Kromydas, T. (2017). Rethinking higher education and its relationship with social inequalities: Past knowledge, present state and future potential. Palgrave Communications, 3. doi: 10.1057/s41599-017-0001-8

Langhout, R. D., Drake, P., \& Rosselli, F. (2009). Classism in the university setting: Examining student antecedents and outcomes. Journal of Diversity in Higher Education, 2, 166-181. doi: $10.1037 / \mathrm{a} 0016209$

Lehmann, W. (2007). "I just didn't feel like I fit in": The role of habitus in university dropout decisions. Canadian Journal of Higher Education, 37, 89-110.

Lehmann, W. (2009). Becoming middle-class: How working-class university students draw and transgress moral class boundaries. Sociology, 43, 631-647. doi: $\underline{10.1177 / 0038038509105412}$ 
Lorant, V., Deliège, D., Eaton, W., Robert, A., Philippot, P., \& Ansseau, M. (2003). Socioeconomic inequalities in depression: A meta-analysis. American Journal of Epidemiology, 157, 98-112. doi: 10.1093/aje/kwf182

Lovibond, S. F., \& Lovibond, P. F. (2004). Manual for the depression anxiety stress scales. The Psychology Foundation of Australia, Sydney, Australia.

Lund, C., Breen, A., Flisher, A. J., Kakuma, R., Corrigall, J., Joska, J. A.,..\&\& Patel, V. (2010). Poverty and common mental disorders in low and middle income countries: A systematic review. Social Science \& Medicine, 71, 517-528. doi: 10.1016/j.socscimed.2010.04.027

Malecki, C. K., \& Demaray, M. K. (2006). Social support as a buffer in the relationship between socioeconomic status and academic performance. School Psychology Quarterly, 21, 375395. doi: $10.1037 / \mathrm{h} 0084129$

Manstead, A. S. (2018). The psychology of social class: How socioeconomic status impacts thought, feelings, and behaviour. British Journal of Social Psychology, 57, 267-291. doi: 10.1111/bjso.12251

Martin, N. D. (2012). The privilege of ease: Social class and campus life at highly selective, private universities. Research in Higher Education, 53, 426-452. doi: 10.1007/s11162-011-9234$\underline{3}$

Martin, Y. M., Maclachlan, M., \& Karmel, T. (2001). Postgraduate completion rates. Department of Education, Training and Youth Affairs, Higher Education Division.

Martinez, J. A., Sher, K. J., Krull, J. L., \& Wood, P. K. (2009). Blue-collar scholars?: Mediators and moderators of university attrition in first-generation college students. Journal of College Student Development, 50, 87-103. doi: 10.1353/csd.0.0053

McConnell, P. J. (2000). ERIC review: What community colleges should do to assist firstgeneration students. Community College Review, 28, 75-87. doi: $\underline{10.1177 / 009155210002800305}$

McGuffog, R. (2018). [Unpublished data.] The University of Newcastle, Australia.

McIntyre, J. C., Worsley, J., Corcoran, R., Harrison Woods, P., \& Bentall, R. P. (2018). Academic and non-academic predictors of student psychological distress: The role of social identity and loneliness. Journal of Mental Health. doi: 10.1080/09638237.2018.1437608

Morioka, T., Ellison, N. B., \& Brown, M. (2016). Identity work on social network sites: Disadvantaged students' college transition processes. In Proceedings of the 19th ACM Conference on Computer Supported Cooperative Work and Social Computing (pp. 848859). New York, NY: ACM. doi: 10.1145/2818048.2819959

National Institute of Medical Health. (2015). Major depression among adults. Retrieved from http://1.usa.gov/1ElBJdO

Ostrove, J. M., \& Long, S. M. (2007). Social class and belonging: Implications for college adjustment. The Review of Higher Education, 30, 363-389. doi: 10.1353/rhe.2007.0028

Parker, S. (2016, $19^{\text {th }}$ February). Inequality in higher education: A class act. Presented to the TJ Ryan Foundation, Brisbane, Australia. Canberra, Australia: University of Canberra. Retrieved from http://apo.org.au/node/61710

Pascarella, E. T., Pierson, C. T., Wolniak, G. C., \& Terenzini, P. T. (2004). First-generation college students: Additional evidence on college experiences and outcomes. The Journal of Higher Education, 75, 249-284.

Pascarella, E. T., \& Terenzini, P. T. (1991). How college affects students: Findings and insights from twenty years of research. San Francisco, CA: Jossey-Bass. 
Pascarella, E. T., \& Terenzini, P. T. (2005). How college affects students Vol. 2: A third decade of research. San Francisco, CA: Jossey-Bass.

Perna, L. W. (2005). The benefits of higher education: Sex, racial/ethnic, and socioeconomic group differences. Review of Higher Education, 29, 23-52. doi: 10.1353/rhe.2005.0073

Pike, G. R., \& Kuh, G. D. (2005). First- and second-generation college students: A comparison of their engagement and intellectual development. Journal of Higher Education, 76, 276-300.

Pittman, L. D., \& Richmond, A. (2007). Academic and psychological functioning in late adolescence: The importance of school belonging. The Journal of Experimental Education, 75, 270-290.

Reid, M. J., \& Moore III, J. L. (2008). College readiness and academic preparation for postsecondary education: Oral histories of first-generation urban college students. Urban Education, 43, 240-261. doi: 10.1177/0042085907312346

Riehl, R.J. (1994). The academic preparation, aspirations, and first-year performance of firstgeneration students. College \& University, 70, 14-19.

Robbins, S. B., Allen, J., Casillas, A., Peterson, C. H., \& Le, H. (2006). Unraveling the differential effects of motivational and skills, social, and self-management measures from traditional predictors of college outcomes. Journal of Educational Psychology, 98, 598. doi: 10.1037/0022-0663.98.3.598

Robbins, S. B., Le, H., Davis, D., Lauver, K., Langley, R., \& Carlstrom, A. (2004). Do psychosocial and study skill factors predict college outcomes? A meta-analysis. Psychological Bulletin, 130, 261-288. doi: 10.1037/0033-2909.130.2.261

Rubin, M. (2012a). Social class differences in social integration among students in higher education: A meta-analysis and recommendations for future research. Journal of Diversity in Higher Education, 5, 22-38. doi: 10.1037/a0026162

Rubin, M. (2012b). Working-class students need more friends at university: A cautionary note for Australia's higher education equity initiative. Higher Education Research and Development, 31, 431-433. doi: 10.1080/07294360.2012.689246

Rubin, M., Denson, N., Kilpatrick, S., Matthews, K. E., Stehlik, T., \& Zyngier, D. (2014). "I am working-class:" Subjective self-definition as a missing measure of social class and socioeconomic status in higher education research. Educational Researcher, 43, 196-200. doi: 10.3102/0013189X14528373

Rubin, M., Evans, O., \& Wilkinson, R. B. (2016). A longitudinal study of the relations between university students' subjective social status, social contact with university friends, and mental health and well-being. Journal of Social and Clinical Psychology, 35, 722-737. doi: $\underline{10.1521 / \text { jscp.2016.35.9.722 }}$

Rubin, M., \& Kelly, B. M. (2015). A cross-sectional investigation of parenting style and friendship as mediators of the relation between social class and mental health in a university community. International Journal for Equity in Health, 14:87, 1-11. doi: 10.1186/s12939015-0227-2

Rubin, M., Paolini, S., Subašić, E., \& Giacomini, A. (2019). A confirmatory study of the relations between workplace sexism, sense of belonging, mental health, and job satisfaction in maledominated industries. Journal of Applied Social Psychology. doi: $10.1111 / \mathrm{jasp} .12577$

Rubin, M., \& Stuart, R. (2018). Kill or cure? Different types of social class identification amplify and buffer the relation between social class and mental health. Journal of Social Psychology, 158, 236-251. doi: 10.1080/00224545.2017.1327405 
Rubin, M., \& Wright, C. L. (2015). Age differences explain social class differences in students' friendship at university: Implications for transition and retention. Higher Education, 70, 427-439. doi: $10.1007 / \mathrm{s} 10734-014-9844-8$

Rubin, M., \& Wright, C. L. (2017). Time and money explain social class differences in students' social integration at university. Studies in Higher Education, 42, 315-330. doi: $\underline{10.1080 / 03075079.2015 .1045481}$

Said, D., Kypri, K., \& Bowman, J. (2013). Risk factors for mental disorder among university students in Australia: Findings from a web-based cross-sectional survey. Social Psychiatry and Psychiatric Epidemiology, 48, 935-944. doi: 10.1007/s00127-012-0574-X

Scevak, J., Southgate, E., Rubin, M., Macqueen, S., Douglas, H., \& Williams, P. (2015). Equity groups and predictors of academic success in higher education. In National Centre for Student Equity in Higher Education, Informing policy and practice: 2014 student equity in higher education research grants program projects (pp. 10-11). Curtin University. Full report available at http://bit.ly/1FU4pgi

Shah, M., Bennett, A., \& Southgate, E. (2016). Widening higher education participation: A global perspective. Waltham: Chandos.

Shields, N. (2002). Anticipatory socialization, adjustment to university life, and perceived stress: Generational and sibling stress. Social Psychology of Education, 5, 365-392.

Soria, K., \& Stebleton, M. (2013). Social capital, academic engagement, and sense of belonging among working-class college students. College Student Affairs Journal, 31, 139-153.

Southgate, E. L., Douglas, H., Scevak, J. J., MacQueen, S. E., Rubin, M., \& Lindell, C. (2014). The academic outcomes of first-in-family in an Australian university: An exploratory study. International Studies in Widening Participation, 1, 31-45.

Stallman, H. M. (2010). Psychological distress in university students: A comparison with general population data. Australian Psychologist, 45, 249-257. doi: 10.1080/00050067.2010.482109

Stephens, N. M., Fryberg, S. A., Markus, H. R., Johnson, C. S., \& Covarrubias, R. (2012). Unseen disadvantage: how American universities' focus on independence undermines the academic performance of first-generation college students. Journal of Personality and Social Psychology, 102, 1178 -1197. doi: 10.1037/a0027143

Stephens, N. M., Hamedani, M. G., \& Destin, M. (2014). Closing the social-class achievement gap: A difference-education intervention improves first-generation students' academic performance and all students' college transition. Psychological Science, 25, 943-953. doi: $10.1177 / 0956797613518349$

Stephens, N. M., Townsend, S. S., Markus, H. R., \& Phillips, L. T. (2012). A cultural mismatch: Independent cultural norms produce greater increases in cortisol and more negative emotions among first-generation college students. Journal of Experimental Social Psychology, 48, 1389-1393. doi: 10.1016/j.jesp.2012.07.008

Strayhorn, T. L. (2012). College students' sense of belonging: A key to educational success for all students. New York: Routledge.

Stuber, J. M. (2009). Class, culture, and participation in the collegiate extra-curriculum. Sociological Forum, 24, 877-900. doi: 10.1111/j.1573-7861.2009.01140.x

Ternes, J. A. (2013). Using social media to engage students in campus life (Doctoral dissertation). Retrieved from http://krex.k-state.edu/dspace/handle/2097/15596

Thoits, P. A. (2011). Mechanisms linking social ties and support to physical and mental health. Journal of Health and Social Behavior, 52, 145-161. doi: 10.1177/0022146510395592 
Tremblay, P. F., \& Rodger, S. (2003). The effects of a peer mentoring program on academic success among first year university students. The Canadian Journal of Higher Education, 33, 1-17.

Verduyn, P., Ybarra, O., Résibois, M., Jonides, J., \& Kross, E. (2017). Do social network sites enhance or undermine subjective well-being? A critical review. Social Issues and Policy Review, 11, 274-302. doi: 10.1111/sipr.12033

Vickers, M., Lamb, S., \& Hinkley, J. (2003). Student workers in high school and beyond: The effects of part-time employment on participation in education, training and work., Camberwell, Australia: Australian Council for Educational Research.

Walton, G. M., \& Cohen, G. L. (2007). A question of belonging: Race, social fit, and achievement. Journal of Personality and Social Psychology, 92, 82-96. doi: 10.1037/0022-3514.92.1.82

Wilcox, P., Winn, S., \& Fyvie-Gauld, M. (2005). 'It was nothing to do with the university, it was just the people': The role of social support in the first-year experience of higher education. Studies in Higher Education, 30, 707-722. doi: 10.1080/03075070500340036

Wolf-Wendel, L., Ward, K., \& Kinzie, J. (2009). A tangled web of terms: The overlap and unique contribution of involvement, engagement, and integration to understanding college student success. Journal of College Student Development, 50, 407-428. doi: 10.1353/csd.0.0077

Yazedjian, A., Toews, M. L., \& Navarro, A. (2009). Exploring parental factors, adjustment, and academic achievement among White and Hispanic college students. Journal of College Student Development, 50, 458-467. doi: 10.1353/csd.0.0080

Yu, P., \& Delaney, J. A. (2016). The spread of higher education around the globe: A cross-country analysis of gross tertiary education enrollment, 1999-2005. Educational Policy, 30, 281321. doi: $10.1177 / 0895904814531648$

Zhang, R. (2017). The stress-buffering effect of self-disclosure on Facebook: An examination of stressful life events, social support, and mental health among college students. Computers in Human Behavior, 75, 527-537. doi: 10.1016/j.chb.2017.05.043

Zorn, T. E., \& Gregory, K. W. (2005). Learning the ropes together: Assimilation and friendship development among first-year male medical students. Health Communication, 17, 211231. doi: $10.1207 / \mathrm{s} 15327027 \mathrm{hc} 1703 \_1$

\section{Endnotes}

1. The concept of working-class is associated with a variety of different labels, including low SES, low social status, underprivilege, disadvantage, low income, and first-generation students at university (for a review, see smith, 2005). In this article, we use the term working-class as a convenient and relatively inclusive label. We acknowledge that alternative terms are somewhat interchangeable but that each also has a distinct meaning.

Funding

The authors declare no funding sources.

\section{Conflict of Interest}

The authors declare no conflict of interest. 